\title{
Nutritional contents and the utilization of Indonesian native starfruits: Averrhoa dolicocarpa and A. leucopetala
}

\author{
FRISCA DAMAYANTI ${ }^{1, \vartheta}$, INGGIT PUJI ASTUTI ${ }^{1, \nu v}$, RIZMOON NURUL ZULKARNAEN $^{1}$, SITI SUNARTI $^{2}$ \\ ${ }^{1}$ Research Center of Plant Conservation and Botanic Gardens, Indonesian Institute of Science. Jl. Ir. H. Djuanda No.13 Bogor 16122, West Java, \\ Indonesia. Tel./fax.+62-251-8311362, ^email: friscad@yahoo.com, ^^email: inggit.pa@gmail.com \\ ${ }^{2}$ Research Center for Biology, Indonesian Institute of Science. Cibinong Science Center, Jl. Raya Jakarta-Bogor Km. 46, Cibinong 16911, Bogor, West \\ Java, Indonesia
}

Manuscript received: 2 January 2020. Revision accepted: 4 March 2020.

\begin{abstract}
Damayanti F, Astuti IP, Zulkarnaen RN, Sunarti S. 2020. Nutritional contents and the utilization of Indonesian native starfruit: Averrhoa dolicocarpa and A. leucopetala. Biodiversitas 21: 1303-1309. Averrhoa dolicocarpa Rugayah \& Sunarti and Averrhoa leucopetala Rugayah \& Sunarti (wild starfruits) are new species of starfruit native to Indonesia. Both species have become plants collection in the Bogor Botanical Gardens (BBG). However, the nutritional content and the utilization of these two species have not been revealed in detail. The species of starfruit that are often widely used by the community are Averrhoa bilimbi and Averrhoa carambola. Therefore, the study aimed to reveal the nutritional content and excavate the potential use of A.dolicocarpa and A.leucopetala. The study was conducted by testing the proximate test, vitamin $\mathrm{C}$ content, total phenol, and experiment of starfruit as processed food ingredients. The result showed that the moisture, ash, fat, protein, and total dietary fiber content of A.dolicocarpa and A.leucopetala were comparable to A.bilimbi and A.carambola, while Vitamin C content and total phenol of A.bilimbi were significantly higher than A.dolicocarpa and A.leucopetala. Furthermore, A.dolicocarpa and A.leucopetala can be used as processed food ingredients, such as starfruit fish soup, healthy drinks, pudding, candy, and syrup. But, more comprehensive study on potential uses of A.dolicocarpa and A.leucopetala were still needed to explore information from both species.
\end{abstract}

Keywords: Processed food ingredients, proximate test, vitamin C, wild starfruit

\section{INTRODUCTION}

Averrhoa (starfruit) is a member of the Oxalidaceae family, which is spread across tropical America and Southeast Asia. Averrhoa commonly known by the community consists of 3 species, namely Averrhoa bilimbi L., Averrhoa carambola L., and Averrhoa microphylla Tardieu. Rugayah and Sunarti (2008) published two new species of Averrhoa members, namely Averrhoa dolicocarpa from the Cyclops of Papua and Averrhoa leucopetala from Panua Gorontalo. Therefore, there are 5 types of Averrhoa members based on The Plants List with the accepted names, namely A. bilimbi, A. carambola, A. dolicocarpa, A. leucopetala and A. microphylla (The Plant List 2010). A. dolicocarpa has been recorded as a collection of Bogor Botanical Gardens since 1988, while A. leucopetala has been recorded as a collection of Bogor Botanical Gardens since 2007 (Sari et al. 2010). As a collection plant, the two new species are widely used as research material plants, including Mangunah et al. (2013) related to the phenology and dynamics of chlorophyll content in flowering of both species. Furthermore, Kapsah et al. (2016) examined the pollen viability and Novianti et al. (2018) related to the fruiting phenology of $A$. dolichocarpa and A. leucopetala.

A. dolicocarpa and A. leucopetala fruit have a similar shape with $A$. carambola. A. dolicocarpa and $A$. leucopetala have a sour taste, the same taste with $A$. bilimbi. Both types of starfruit have not known and used directly by the community. The people only know and utilize two types of starfruit, A. bilimbi, and A. carambola, as a food ingredient, cooking spices, and traditional medicine (Yan et al. 2013). A. bilimbi is commonly known as belimbing wuluh or belimbing asam as local name (Alhassan and Ahmed 2017). On the other hand, $A$. carambola is popularly known as belimbing besi or belimbing manis as local name. A.carambola was reported to be a good source of antioxidants and very high in phenolics (Mahattanatawee et al. 2006).

It is necessary to excavate the potential of $A$. dolichocarpa and A. leucopetala, so that, these two types of star fruit have more economic value and competitiveness with the other fruits. In the study, we conducted a proximate test, vitamin $\mathrm{C}$ test, total phenol, and we tried to do some experiments making foods derived from $A$. dolicocarpa and A. leucopetala such as starfruit fish soup, syrup, cake, candy, and healthy drink. The purpose of the study was to reveal the nutritional content and develop the potential of $A$. dolicocarpa and A. leucopetala fruits as processed food ingredients the same as two close relatives of starfruit, A. bilimbi, and A. carambola.

\section{MATERIALS AND METHODS}

The study used a fresh sample of A. dolicocarpa and A. leucopetala fruit which were ripe, yellowish-green in color, fresh, and healthy. Both of them were collection plants of 
Bogor Botanic Gardens. A. dolicocarpa fruit samples were taken from area VII.D.96-96a and A. leucopetala were taken from area XXIV.B.79.

\section{Vitamin C test}

The test of vitamin C used HPLC method. Vitamin C test refers to Jubahar et al. (2015). The first was extraction of samples by maceration method. Then a quantitative Vitamin C test was performed.

\section{Preparation of vitamin C main solution $100 \mathrm{mg} / \mathrm{mL}$}

Vitamin $\mathrm{C}$ was weighed as much as $50 \mathrm{mg}$ then put into a $100 \mathrm{~mL}$ volumetric flask and dissolved with aquabidest to so that a concentration of $500 \mu \mathrm{g} / \mathrm{mL}$ was obtained. Then pipetted $10 \mathrm{~mL}$ solution of $500 \mu \mathrm{g} / \mathrm{mL}$ Vitamin $\mathrm{C}$ into a 50 $\mathrm{mL}$ volumetric flask so that a concentration of $100 \mu \mathrm{g} / \mathrm{mL}$ of vitamin $\mathrm{C}$ was obtained.

\section{Calibration curve}

Vitamin C solution $(100 \mu \mathrm{g} / \mathrm{mL})$ was pipetted into a 10 $\mathrm{mL}$ volumetric flask each of $0.4 \mathrm{~mL}, 0.6 \mathrm{~mL}, 0.8 \mathrm{~mL}, 1 \mathrm{~mL}$ and $1.2 \mathrm{~mL}$, the cpncentration become $4 \mu \mathrm{g} / \mathrm{mL}, 6 \mu \mathrm{g} / \mathrm{mL}$, $8 \mu \mathrm{g} / \mathrm{mL}, 10 \mu \mathrm{g} / \mathrm{mL}$ and $12 \mu \mathrm{g} / \mathrm{mL}$. Metaphosphoric acid (MPA) $0.56 \% \mathrm{w} / \mathrm{v}$ was added until the limit markers and homogenized. The solution was filtered with filter size 0.45 $\mu \mathrm{m}$, and then injected until it get an area. The linear regression equation was determined $y=a+b x$ and the correlation value.

\section{Determination of vitamin C levels}

Weighed $50 \mathrm{mg}$ of crystal and put it into a $100 \mathrm{~mL}$ volumetric flask, then added with metaphosphoric acid (MPA) $0.56 \% \mathrm{w} / \mathrm{v}$ until the boundary markers. It was filtered with filter paper in a $100 \mathrm{~mL}$ volumetric flask and added with metaphosphoric acid (MPA) $0.56 \%$ w/v until the mark limit. Then pipetted $2 \mathrm{~mL}$ the solution and put into a $10 \mathrm{~mL}$ volumetric flask, then added metaphosphoric acid (MPA) $0.56 \% \mathrm{w} / \mathrm{v}$ to the boundary mark. Furthermore, the crystalline solution was filtered with a $0.45 \mu \mathrm{m}$ filter and then injected into HPLC with a mobile phase of $0.1 \%$ acetic acid and methanol (95: 5).

\section{Proximate test}

Proximate test was conducted at the Department of Zoology, Research Center for Biology, Indonesian Institute of Science. The proximate test refers to SNI 01-2891-1992.

\section{Water content}

The measurement of water content was as follows, 1 gram of sample was weighted in a porcelain cup, then put in an oven $105^{\circ} \mathrm{C}$ for 8 hours. The samples were weighted and water content can be calculated by formula:

$$
\text { Water content }=\frac{\text { weight of sample }}{\text { weight of fresh sample }} \times 100 \%
$$

\section{Ash content}

Measurement of ash content was as follows, 1 gram of sample was placed in a porcelain cup and then burned until it was not smoky, then boltted in a furnace at $600^{\circ} \mathrm{C}$ for 4 hours and weighed. Ash content can be calculated by the formula:

$$
\text { Ash content }=\frac{\text { weight of ash }}{\text { weight of sample }} \times 100 \%
$$

\section{Fat content}

Measurement of fat content by Hydrolysis-Soxhlet method was as follow, 2 grams of sample was rolled using filter paper and put into a soxhlet flask. The sample was extracted for 6 hours with $150 \mathrm{ml}$ of fat solvent (hexane). The extracted fat was dried in an oven at $100^{\circ} \mathrm{C}$ for 1 hour. Fat content can be calculated by the formula:

$$
\text { Fat content }=\frac{\text { weight of fat }}{\text { weight of sample }} \times 100 \%
$$

\section{Protein content}

Measurement of protein content by Micro Kjeldahl method was as follows, 0.25 grams of sample was put into a $100 \mathrm{ml}$ Kjeldahl flask, it was added 0.25 grams selenium and $3 \mathrm{ml}$ of concentrated $\mathrm{H} 2 \mathrm{SO} 4$. Then the sample was degraded for 1 hour until the solution becomes clear. After chilling, added $50 \mathrm{ml}$ of distilled water and $20 \mathrm{ml}$ of $40 \%$ $\mathrm{NaOH}$ and distilled. The distillation results were collected in an Erlenmeyer flask containing a mixture of $10 \mathrm{ml}$ of $2 \%$ H3BO3 and 2 drops of Brom Cresol Green-Methyl Red indicator. After the distillate volume becomes $10 \mathrm{ml}$ and turns bluish-green, the distillation was stopped and the distillate was titrated with $0.1 \mathrm{~N} \mathrm{HCl}$ until it has a pink color. The same treatment was done with blanks. The total nitrogen levels calculated by the formula:

$$
\% N=\frac{(S-B) \times N H C l \times 14}{w \times 1000} \times 100 \%
$$

Where:

S: volume of titrant sample $(\mathrm{ml})$

B: volume of titrant blanko $(\mathrm{ml})$

w: the weight of dried sample (mg)

\section{Total dietary fiber}

Measurement total dietary fiber was as follows, 1 gram of sample was dissolved with $100 \mathrm{ml}$ of $1.25 \% \mathrm{H} 2 \mathrm{SO} 4$, heated to boiling and then destroyed for 30 minutes. The results are filtered with filter paper and Buchner funnel. The filter residue is rinsed with $20-30 \mathrm{ml}$ of boiling water and $25 \mathrm{ml}$ of water 3 times. The residue was redistributed with $1.25 \% \mathrm{NaOH}$ for 30 minutes then filtered and rinsed with $25 \mathrm{ml}$ boiling $1.25 \% \mathrm{H} 2 \mathrm{SO} 4,25 \mathrm{ml}$ water and $25 \mathrm{ml}$ alcohol. the residue and filter paper are transferred to the porcelain cup and dried in a $130 \mathrm{C}$ oven for 2 hours. After chilling the residue along with the porcelain cup was weighed (A), then put in a $600 \mathrm{C}$ furnace for 30 minutes, cooled and re-weighed (B).

Gross fiber weight $=\mathrm{W}-\mathrm{W}^{\circ}$

$\mathrm{W}=$ residual weight before burning in the furnace = A-(weight of filter paper + cup $)$ : A: residual weight + filter paper + cup

$\mathrm{W}^{\mathrm{o}}=$ weight of residue after burning in the furnace = B-(cup weight): B: residual weight + cup 


\section{Total phenol}

Total phenol test was conducted at the Laboratory of the Department of Food Science and Technology, Faculty of Agricultural Technology, IPB. Total phenol test used spectrophotometry method. Total phenol test refers to Benites et al. (2015).

\section{Extract preparation}

For preparing the extracts, the fruit was dried and powdered and extracted by maceration with methanol/water (8:2), at room temperature. The extract was filtered, concentrated under pressure in a rota evaporator at $50^{\circ} \mathrm{C}$, and lyophilized. The crude extracts were determined from the mass of the material prior to extraction and the mass of extract obtained after removal of methanol/water. The extraction yield was calculated in percentage after weighing.

\section{Determination of total phenol extract of star fruit}

The total phenol content of the samples was determined using the Folin-Ciocalteau reagent. Briefly, $100 \mu \mathrm{L}$ of extracts in methanol $(1 \mathrm{~g} / \mathrm{L})$ was mixed with $1.0 \mathrm{~mL}$ of distilled water and $0.5 \mathrm{~mL}$ of Folin-Ciocaleu's $(1: 10 \mathrm{v} / \mathrm{v})$ reagent. Then $1.5 \mathrm{ml}$ of $2 \%$ sodium bicarbonate was added, and the mixture was allowed to stand for $30 \mathrm{~min}$ with shaking. The absorbance was measured at $765 \mathrm{~nm}$ using a spectrophotometer. The total phenolic content was determined as a gallic acid equivalent (GAE) in milligrams per gram $(\mathrm{mg} / \mathrm{g})$ of extract. The methanol solution was used as a blank.

\section{Experiment of processed food from wild starfruit}

In this study, we made processed food from wild starfruit, including starfruit fish soup, healthy drink, syrup, pudding, and candy. The recipe used in this experiment refers to the recipe commonly used by Indonesian people.

\section{Starfruit Fish Soup}

The trial of making fish soup was conducted at Treub Laboratory, Bogor Botanical Gardens. The ingredients needed for making starfruit fish soup were 300 grams of goldfish, 100 grams of carrots, 3 cloves of garlic, 5 cloves of onion, a little ginger, 3 sheets of bay leaves, lemongrass, $400 \mathrm{ml}$ of water, salt, and sugar. Spices such as garlic, onion, and ginger were ground until smooth. Carrot and starfruit have been sliced. The boiling water was added with sliced carrots, mashed spices, and fish. Then, as many as 3 starfruits (A. dolicocarpa, A. leucopetala, and $A$. bilimbi) was added to each soup. The last, enough of salt and sugar was added to taste. Starfruit fish soup was ready to be served

\section{Healthy Drink}

The water was heated until boiling, then the cutting fruit of the A. leucopetala and the brown sugar were added into boiled water. It has waited until the sugar dissolves. It was filtered and waited until the drink was cool. The drink is ready to be served.
Syrup

The trial of making syrup collaborated with Small and Medium Enterprise activists. Starfruit was washed thoroughly, then pricked with a fork and placed in a pan that contains 500 grams of sugar, and $1000 \mathrm{ml}$ of water. It was heated until boiling, then added 1 tablespoon of salt, stirred until cool then it was filtered and put in a bottle.

\section{Pudding}

The trial of making pudding collaborated with Small and Medium Enterprise activists. First, to make yellow pudding, 150 gr cutting fruit of A. dolicocarpa or A. leucopetala was soaked in saltwater for 1 hour and blended. Then, 4 tablespoons of sugar and jelly powder were added into $700 \mathrm{ml}$ of water, stirred until smooth and cooked until boiling. After that, it was printed in molds. It has waited until harden. White pudding was made from 1 packet of jelly powder, sweetened condensed milk, 8 tablespoons of sugar were put into $800 \mathrm{ml}$ water and cooked until boiling. The last, the yellow pudding was put upside-down, and the white pudding was poured into the molds that contain the yellow pudding. It has waited until harden.

\section{Candy}

The trial of making candy collaborated with Small and Medium Enterprise activists. The candy could be made from mixing between the starfruit fruit and banana. The starfruit and banana candy was made with 85 gr $A$. dolicocarpa or A. leucopetala, then it was added 85 grams of sugar and 150 grams of banana. Then, it was crushed and cooked over low heat until it could be rounded.

\section{RESULTS AND DISCUSSION}

\section{Proximate analysis, vitamin $\mathrm{C}$, and total phenol of $A$. dolicocarpa dan A. leucopetala}

In this study, we conducted proximate test, vitamin $\mathrm{C}$ content, and total phenol of A. dolicocarpa and $A$. leucopetala. A. bilimbi and A. carambola were used as a comparison of two other types of starfruit because $A$. bilimbi and $A$. carambola have been widely used by the community and there have been many studies that discuss the two types of starfruit (Yan et al. 2013). The proximate test of A. dolicocarpa and A. leucopetala is shown in Table 1.

We used three types of starfruit, A.dolicocarpa, A.leucopetala, and A.bilimbi for analysis of vitamin $\mathrm{C}$ and total phenols. The results of the vitamin $\mathrm{C}$ and total phenols test are shown in Table 2.

\section{Experiment of starfruit as processed food material}

Averrhoa dolicocarpa and A.leucopetala can be used as processed food ingredients, such as cooking spices for fish soup, healthy drinks, pudding, candy, and syrup. The experiments making foods derived from A. dolicocarpa and A. leucopetala is shown in Figure 1-4. 
Table 1. Proximate analysis of Averrhoa dolicocarpa and A. leucopetala

\begin{tabular}{lccccc}
\hline \multirow{2}{*}{ Samples name } & \multicolumn{5}{c}{ Type of testing } \\
\cline { 2 - 6 } & Moisture (\%) & Ash (\%) & Protein (\%) & Fat (\%) & Total dietary fiber (\%) \\
\hline A. dolicocarpa & $15.56 \mathrm{~b}$ & $6.89 \mathrm{a}$ & $9.28 \mathrm{~b}$ & $4.30 \mathrm{~b}$ & $11.94 \mathrm{c}$ \\
A. leucopetala & $16.57 \mathrm{a}$ & $5.67 \mathrm{~b}$ & $9.59 \mathrm{~b}$ & $6.25 \mathrm{a}$ & $12.96 \mathrm{~b}$ \\
A. bilimbi & $16.84 \mathrm{a}$ & $4.62 \mathrm{c}$ & $11.50 \mathrm{a}$ & $3.38 \mathrm{c}$ & $15.31 \mathrm{a}$ \\
A. carambola* & $12.04 \mathrm{c}$ & $3.87 \mathrm{~d}$ & $7.88 \mathrm{c}$ & $1.36 \mathrm{~d}$ & $7.89 \mathrm{~d}$ \\
\hline
\end{tabular}

Note: Means in a column within a group with the same letter are not statistically different $(\mathrm{P}<0.05)$. *) Source for proximate analysis of A. bilimbi and A. carambola: Yan et al. (2013)

Table 2. Vitamin $\mathrm{C}$ content and total phenol Averrhoa dolicocarpa, A. leucopetala, and A. bilimbi

\begin{tabular}{lll}
\hline \multicolumn{1}{c}{ Samples } & \multicolumn{1}{c}{$\begin{array}{c}\text { Vitamin C } \\
(\mathbf{m g} / \mathbf{1 0 0} \mathbf{~ g})\end{array}$} & $\begin{array}{c}\text { Total phenol } \\
(\mathbf{m g} / \mathbf{1 0 0 0 g})\end{array}$ \\
\hline A. dolicocarpa & $7.76 \mathrm{c}$ & $67.21 \mathrm{c}$ \\
A. leucopetala & $18.7 \mathrm{~b}$ & $208.22 \mathrm{~b}$ \\
A. bilimbi & $20.0 \mathrm{a}$ & $647.62 \mathrm{a}$ \\
\hline
\end{tabular}

Note: Means in a column within a group with the same letter are not statistically different $(\mathrm{P}<0.05)$

\section{Discussion}

Moisture content is one of the characteristics in food ingredients because it can affect the appearance, texture, and taste. Water content also determines the freshness and storability of the food. Based on the proximate analysis in Table 1 it indicated that both types of star fruit contain high water content. A. dolicocarpa had a water content of about $15.56 \%$, while A. leucopetala about $16.57 \%$. When compared with two other types of starfruit, A. leucopetala and $A$. dolicocarpa had lower water content than $A$. bilimbi (16.84\%), and higher than A. carambola (12.04\%) (Yan et al. 2013 ). Furthermore, measurement of ash content aims to determine the amount of mineral content in food. Ash content obtained was $6.89 \%$ in A. dolicocarpa, and $5.67 \%$ in A. leucopetala. Ash content of two types of starfruit was higher than A. bilimbi (4.62\%) and A. carambola (3.87\%). Mineral content of $A$. dolicocarpa and A. leucopetala was comparable to A. bilimbi and A. carambola as total mineral content of the fruits. Table 1 indicated that water content and ash content were inversely proportional. The higher water content, the ash content will be smaller. Ash content in food is related to inorganic mineral content. A food contains mostly organic matter and water, the rest is inorganic compound called mineral or ash. High ash content can be caused by the presence of unburnt mineral content such as $\mathrm{Na}, \mathrm{Ca}$ and $\mathrm{P}$ (Landeng et al. 2017).

The results of the protein content of A. dolicocarpa obtained $9.28 \%$ and A. leucopetala $9.59 \%$. The results obtained from the two wild starfruits were not significantly different. Furthermore, the result was lower than the protein content of $A$. bilimbi $(11.50 \%)$, and higher than $A$. carambola $(7.88 \%)$. On the other hand, fats content of $A$. dolicocarpa was about $4.30 \%$ and A. leucopetala was about $6.25 \%$. Fat content in both types of star fruit was higher significantly than A. bilimbi at $3.38 \%$, and A. carambola at $1.36 \%$. In Table 1, the levels of total dietary fiber in $A$. dolicocarpa was $11.94 \%$ and A. leucopetala was $12.96 \%$. These results indicated a lower value than $A$. bilimbi (15.31\%), and higher than A. carambola $(7.89 \%)$. Total dietary fiber is a complex form of carbohydrate food that is widely available in the cell walls of food plants. Total dietary fiber cannot be digested and absorbed by the human, but has a very important function for healthy, disease prevention and as an important component in nutritional therapy. World Health Organization (WHO) recommends a good fiber intake is about 25-30 grams per day (Rahmah et al. 2017).

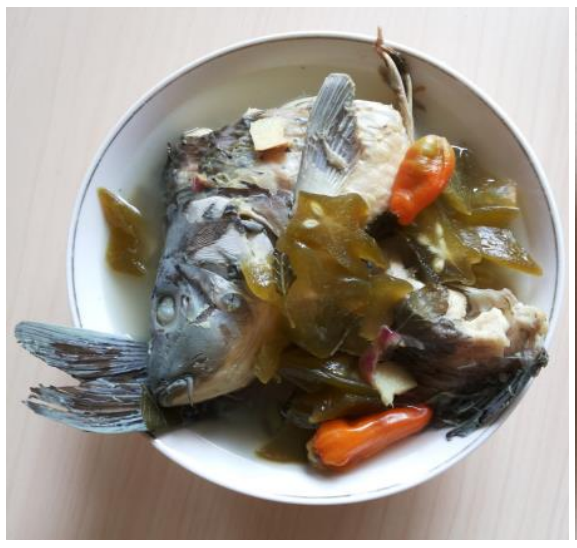

$\mathbf{A}$

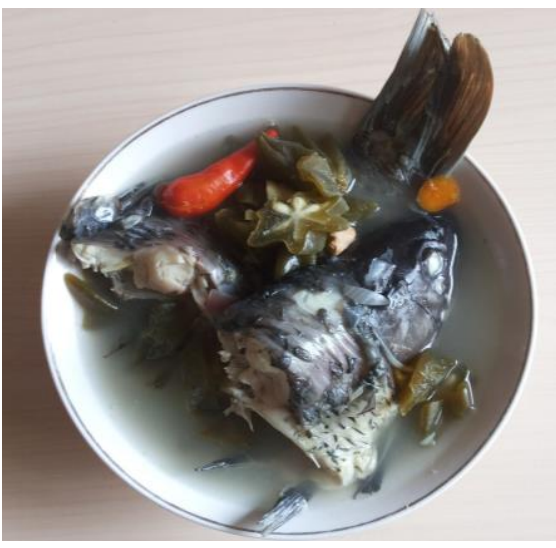

B

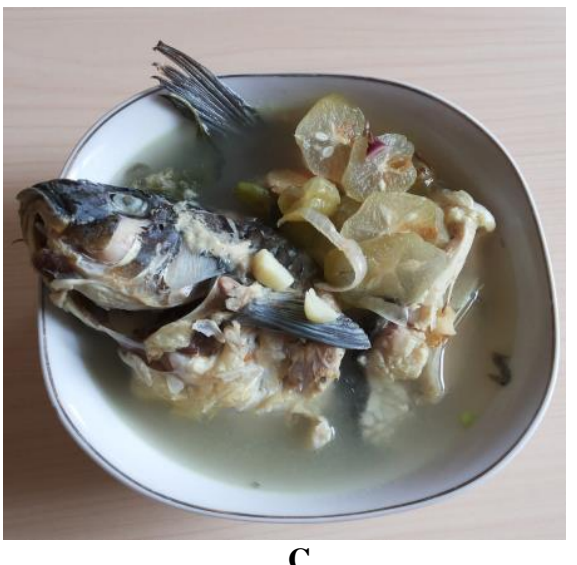

C

Figure 1. Starfruit fish soup. A. A. dolicocarpa, B. A. leucopetala, C. A. bilimbi 


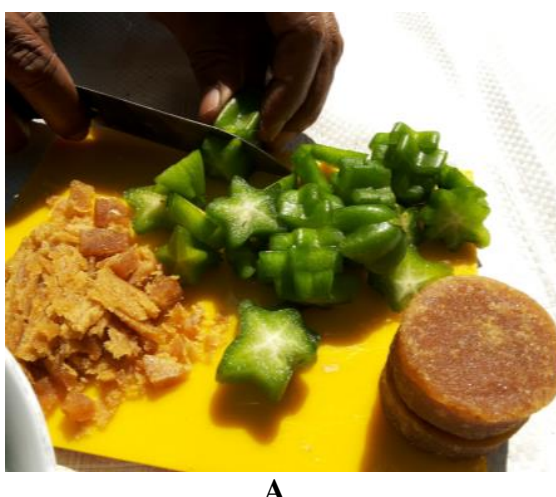

A

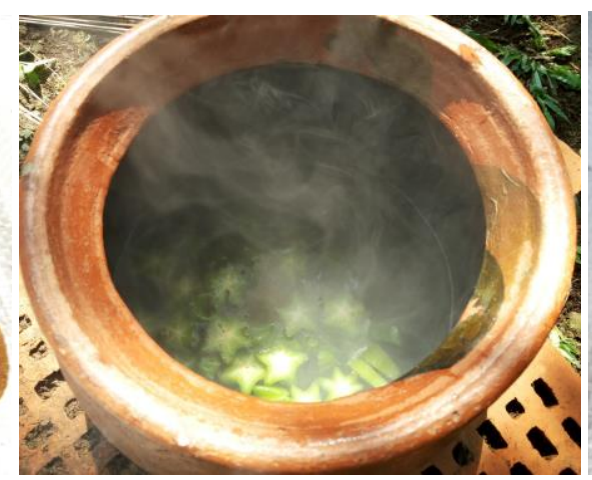

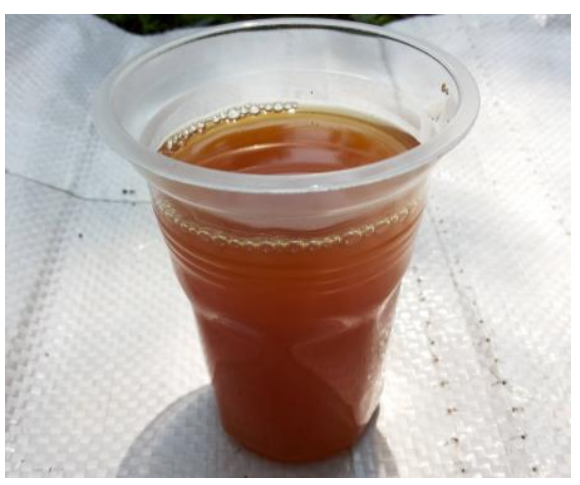

C

Figure 2. Starfruit healthy drink. A-B. The process of making healthy drink, C. Starfruit healthy drink
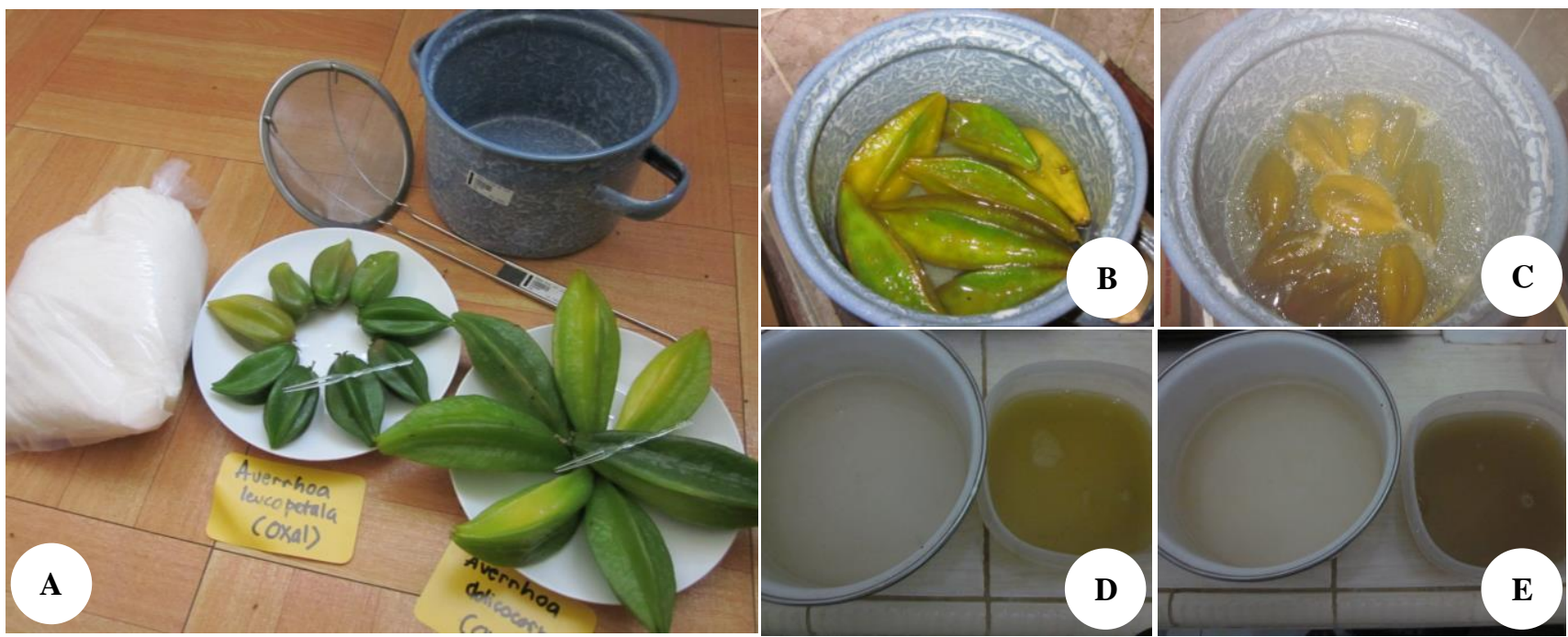

Figure 3. Starfruit Syrup. A-C. The process of making starfruit syrup, D. A. dolicocarpa syrup, E. A. leucopetala syrup
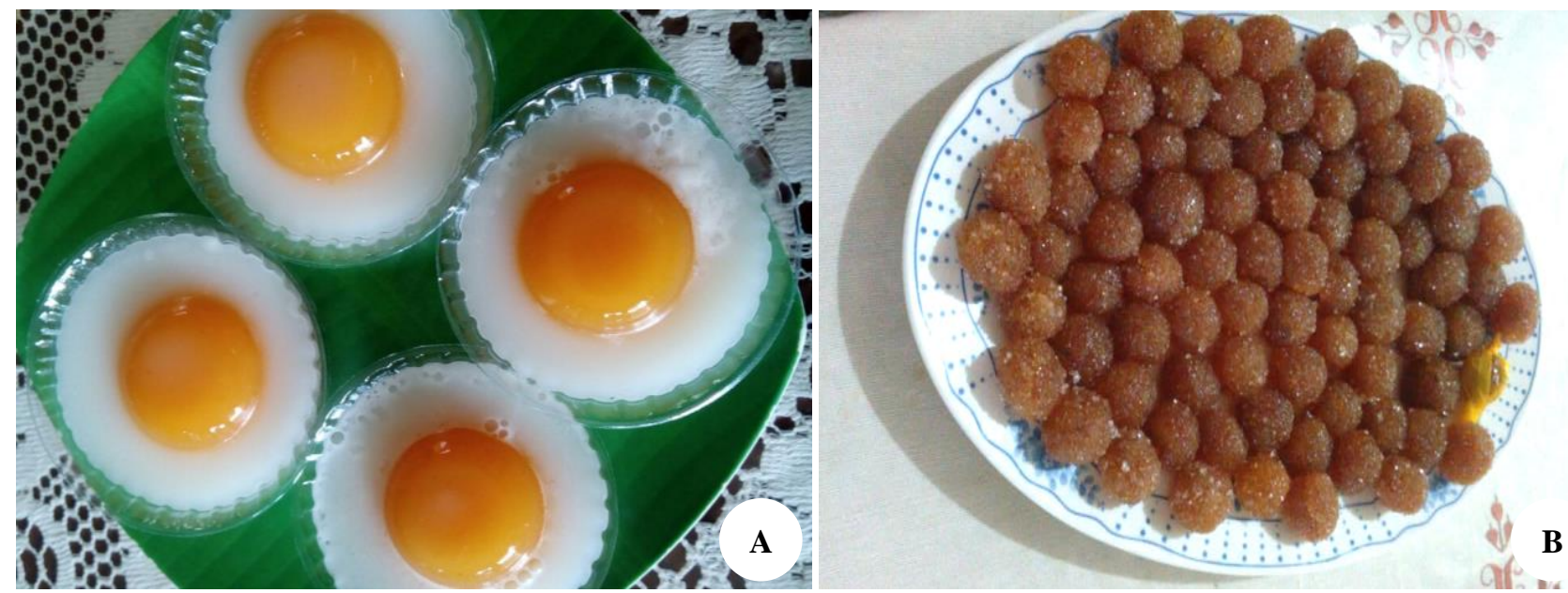

Figure 4. A. Sunnyside up pudding; B. Starfruit candy 
Based on Table 2 showed that the vitamin $\mathrm{C}$ content of A. dolicocarpa was $7.76 \mathrm{mg} / 100 \mathrm{~g}$, A. leucopetala was 18.7 $\mathrm{mg} / 100 \mathrm{~g}$, and A. bilimbi was $20.0 \mathrm{mg} / 100 \mathrm{~g}$. According to Sari (2018), the content of vitamin C in A. bilimbi ranged from $10.65-14.13 \mathrm{mg} / 100 \mathrm{~g}$, while according to Chaerunisa (2018) reported that the content of A.bilimbi juice was $27.22 \mathrm{mg} / 100 \mathrm{~g}$. It indicates that based on the result and Chaerunisa (2018) the vitamin C content of A.leucopetala and A.dolicocarpa has a lower value than A.bilimbi. Vitamin $\mathrm{C}$ content in $A$. leucopetala had significantly different from A.bilimbi, and A. dolicocarpa. Moreover, from the tree starfruit, A. dolicocarpa has the lowest Vitamin $\mathrm{C}$ content. It can be caused by environmental factors, such as climate, soils, and light exposure, that play important roles in influencing vitamin $\mathrm{C}$ content, as is known that A. dolicocarpa, A. leucopetala, and A. bilimbii are planted in Bogor Botanic Gardens but in different area. Furthermore, it might have loss during sample preparation or extraction as vitamin $\mathrm{C}$ is very susceptible to light, heat, and air (El-Ishaq and Obirinakem 2015). The current recommended dietary allowance (RDA) for vitamin $\mathrm{C}$ for adult men and women, is about $75 \mathrm{mg} /$ day for women and $90 \mathrm{mg} /$ day for men. The lack of vitamin $\mathrm{C}$ in body can cause several health problems, such as scurvy, a pathological condition leading to blood vessel fragility and connective tissue damage due to failure in producing collagen, and, finally, collapse and to death (Grosso et al. 2013).

The results of total phenol of three types of starfruit were A. dolicocarpa about $67.21 \mathrm{mg} / \mathrm{kg}$, A. leucopetala $208.22 \mathrm{mg} / \mathrm{kg}$, and A.bilimbi of $647.62 \mathrm{mg} / \mathrm{kg}$. However, the value indicated that $A$. dolicocarpa and A. leucopetala had smaller values compared to A. bilimbi. According to Benites et al. (2015), phenolic compounds are secondary metabolites derived from phenylalanine and tyrosine synthesized by plants during normal development, and also in response to stress conditions. In food, phenolics may contribute to the bitterness, astringency, color, flavor, odor, and oxidative stability of the products. Phenolic compounds play a role in antioxidant and antimicrobial properties, which are known to exert preventive activity against infectious and degenerative diseases, inflammation and allergies via antioxidants, antimicrobial, and proteins, enzymes neutralization or modulation mechanisms (Ozcan et al. 2014).

Wild starfruit (A. dolicocarpa and A. leucopetala) has good nutritional content. It is necessary to utilize the fruit to fulfill their nutritional needs. The problem is $A$. dolicocarpa and A. leucopetala have a sour taste so that these two star fruits are not utilized by the community. Therefore, in this study we did some experiments making food from wild starfruit, so that wild starfruit can be used by the community and has high competitiveness with other fruits. We have done some experiments of starfruit as processed food ingredients such as starfruit fish soup, syrup, cake, candy, and healthy drink.

Most people do not like fish soup because of the fishy smell and fishy taste found in fish and soup broth. It was could be overcome by giving fresh fruit such as pineapple, star fruit, and lemon. In this study, we tried to make fish soup with extra starfruit to add the flavor to the fish soup (Figure 1). The result of the experiment was the colors of A. bilimbi sop more attractive than $A$. dolicocarpa and $A$. leucopetala. A.leucopetala fruit has a dark green color which makes the soup look less attractive. A. dolicocarpa and $A$. bilimbi broth taste more delicious compared to $A$. leucopetala. A. leucopetala has an overly sour taste which can reduce the flavor of fish soup. A. dolicocarpa has the best aroma of soup that increase appetite. The fishy smell in fish soup has disappeared and becomes a fresh aroma that was appetizing.

Indonesian people believed that various types of boiled plants have potential as medicine, including health drinks from starfruit. In this study, we made healthy drinks from starfruit (Figure 2). It was believed by some employees of Bogor Botanical Gardens that after drinking healthy drinks from starfruit, some health problems they experienced, such as dizziness and high blood pressure, become cured. However, further research is needed to prove the potential of $A$. dolicocarpa starfruit as a medication for dizziness and high blood pressure. On the other hand, traditionally, $A$. bilimbi has been widely used as a medicine for the treatment of several diseases such as antidiabetic, antihypertensive, thrombolytic, antimicrobial, antioxidant, hepatoprotective, and hypolipidemic agent (Alhassan and Ahmed 2017).

Syrup is a type of refreshing drink in the form of a solution containing sucrose. According to Satuhu (2004), syrup is divided into 3, namely fruit syrup, essences syrup, and glucose syrup. Fruit syrup is a syrup whose taste and aroma are determined by its basic ingredient, which is fruit. Fruit syrup usually contains sugar and acids. The results of the making syrup are presented in Figure 3. The result of the experiment were both types of syrup had a sweet, sour, and fresh taste. The texture was liquid and not thick. The color of A. dolicocarpa syrup was more interesting compared to A. leucopetala. The taste of A.leucopetala was sourer than A. dolicocarpa. So, it needed to be optimized the amount of sugar needed to make syrup with more delicious taste.

Pudding is a dessert that has a sweet taste and is made from boiled custard ingredients. Pudding can be made with a variety of shapes and colors in accordance with the wishes of the maker. In this study, we made sunny side up pudding. The experimental results are shown in Figure 4.A. The result of the experiments, the pudding has a very attractive color. The white pudding has a sweet taste, while the yellow pudding has a sweet and sour taste like starfruit. The texture of the pudding feels soft. Overall, the pudding has a good taste.

Candy is a processed food product that is widely favored by people of all types of age groups, especially children. This is because candy has an interesting taste, colors, and shapes (Siregar et al. 2016). In the study, we made starfruit candy which was formed into round and coated with sugar, like ginger candy. The results of making starfruit candy show in Figure 4.B. The taste of candy is delicious, sweet, and sour. Generally, starfruit candy has 
good taste. But there were some deficiencies of the candy, such as the texture of the candy was too soft, and less hard, so when candy was eaten, it will quickly break down and run out. Moreover, the color was less attractive because it was brown. In fact, candy is made into attractive colors like yellow, red, green, and orange. So, it was necessary to optimize the appropriate ingredients and add other ingredients to get the attractive color, hard and solid texture of the candy.

The results of proximate analysis, the content of vitamin $\mathrm{C}$, and the total phenol, showed that $A$. dolicocarpa and A. leucopetala fruits have good nutritional content, so they can be utilized and developed by community. Moisture, ash, fat, protein, and total dietary fiber content of A. dolicocarpa and A. leucopetala were comparable to $A$. bilimbi and $A$. carambola, while Vitamin $\mathrm{C}$ content and total phenol of $A$. bilimbi were significantly higher than $A$. dolicocarpa and A. leucopetala. A. dolicocarpa and A. leucopetala can be used as processed food ingredients, such as cooking spices for fish soup, health drinks, pudding, candy, and syrup.

\section{ACKNOWLEDGEMENTS}

The authors would like to thank the Head of Treub Laboratory that has been facilitated us to use equipment to trial make the fish soup, Hera Mardiana as Small and Medium Enterprise activist, and to all respondents who have given their opinions and input to our products.

\section{REFERENCES}

Alhassan MA, Ahmed QU. 2017. Averrhoa bilimbi Linn.: A review of its ethnomedicinal uses, phytochemistry, and pharmacology. J Pharm Bioallied Sci 8 (4): 265-271.

Benites RSR, Formagio ASN, Argandona EJS, Volobuff CRF, Trevizan LNF, Vieira MC, Silva MS. 2015. Content of constituents and antioxidant activity of seed and pulp extracts of Annona coriacea and Annona sylvatica. Braz J Biol 75 (3): 685-691.

Chaerunisa C. 2018. Antioxidant Activity and Characteristics of Starfruit (Belimbing Wuluh) and Curcuma Processed Beverages. [Thesis]. Pasundan University, Bandung. [Indonesian]

El-Ishaq A, Obirinakem S. 2015. Effect of Temperature and Storage on Vitamin C Content in Fruits Juice. Int J Chem Biomol Sci 1 (2):1721 .
Grosso G, Bei R, Mistretta A, Marventano S, Calabrese G, Masuelli L, Giganti MG, Modesti A, Galvano F, Gazzolo D. 2013. Effects of Vitamin C on Health: A Review of Evidence. Front Biosci 1 (18): 1017-1029.

Jubahar J, Astuti Y, Suharti N. 2015. Penetapan kadar vitamin C dari buah cabe rawit (Capsicum frutescens L.) dengan metode Kromatografi cair kinerja tinggi (KCKT). Jurnal Farmasi Higea 7 (2): 208-217. [Indonesian]

Kapsah, Dorly, Astuti IP. 2016. Morphology and Pollen Viability of Two Wild Starfruit Species (Averrhoa dolicocarpa and Averrhoa leucopetala). Buletin Kebun Raya 19 (2): 79-90. [Indonesian]

Landeng, PJ, Suryanto E, Momuat LI. 2017. Proximate Test and Antioxidant Potential from Yellow Manado Corn Seed (Zea mays L.). Chem Prog 10 (1): 36-44

Mahattanatawee K, Manthey JA, Luzio G, Talcott ST, Goodner K, Baldwin EA. 2006. Total antioxidant activity and fiber content of select Florida-grown tropical fruits. J Agric Food Chem 54: 73557363.

Novianti S, Ismanto, Astuti IP. 2018. Comparative Study on the Fruit Development of Two Types Forest Starfruit (Averrhoa dolicocarpa Rugayah \& Sunarti and Averrhoa leucopetala Rugayah \& Sunarti). [Thesis]. Pakuan University, Bogor. [Indonesia]

Mangunah, Qayim I, Astuti IP. 2013. Phenology and dynamics of chlorophyll content in the flowering of two forest starfruit species (Averrhoa dolicocarpa and Averrhoa leucopetala). Buletin Kebun Raya 15 (2):101-113. [Indonesian]

Ozcan T, Akpinar-Bayizit A, Yilmas-Ersan L, Delikanli B. 2014. Phenolics in Human Health. Int J Chem Eng Appl 5 (5): 393-396.

Rahmah AD, Rezal F, Rasma. 2017. Fiber Consumption Behavior of 2013 Students of Faculty of Health Halu Oleo University 2017. Jurnal Ilmiah Mahasiswa Kesehatan Masyarakat 2 (6): 1-10. [Indonesian]

Rugayah, Sunarti S. 2008. Two New Wild Species of Averrhoa (Oxalidaceae) from Indonesia. Reinwardtia 12 (4):325-331.

Sari R, Ruspandi, Ariati SR. 2010. An Alphabetical List of Plant Species Cultivated in The Bogor Botanic Gardens. Indonesian Institute of Sciences, Center for Plant Conservation Bogor Botanic Gardens. Bogor. [Indonesian]

Sari U. 2018. Determination of Vitamin C Levels OF Starfruit (Averrhoa bilimbi) Young and Older with 2,6-Diklorophenol Indophenol Methods. [Thesis]. Polytechnic of Health, Palembang. [Indonesian]

SNI 01-2891-1992. Cara Uji Makanan dan Minuman. Pusat Standarisasi Industri, Departemen Industri, Jakarta. [Indonesian]

Satuhu S. 2004. Fruit Handling and Processing. Penebar Swadaya. Jakarta. [Indonesian]

Siregar R, Harun N, Yusmarini. 2016. Utilization of Sweet Star Fruit (Averrhoa carambola L.) and Pineapple Fruit (Ananas comosus L.) in the Manufacture of Jelly Candy. JOM Faperta 3 (1). [Indonesian]

The Plant List. 2010. Averrhoa. http://www.theplantlist.org/. [1 October 2019].

Yan SW, Ramasamy R, Alitheen NBM, Rahmat A. 2013. A comparative assessment of nutritional composition, total phenolic, total flavonoid, antioxidant capacity, and antioxidant vitamins of two types of Malaysian underutilized fruits (Averrhoa bilimbi And Averrhoa carambola). Intl J Food Prop 16:1231-1244. 